\title{
COUNTRY ASPECTS OF USE OF TAX INSTRUMENTS ON THE HYDROCARBON MARKET
}

\author{
Elena Igorevna Artemova ${ }^{1}$, Olga Yuryevna Voronkova ${ }^{2}$, Alexey Vladimirovich Kulchitsky ${ }^{3}$, \\ Tatiana Victorovna Morozova ${ }^{4}$, Ravil Gabdullaevich Akhmadeev ${ }^{4 *}$, Vladimir Mikhailovich Plosky ${ }^{5}$ \\ ${ }^{1}$ Kuban State Agrarian University, Department of Economic Theory, Named after I.T. Trubilin, \\ Krasnodar, Russian Federation; \\ ${ }^{2}$ Altai State University, Department of Management, Business Organization and Innovation, \\ Barnaul, Russian Federation; \\ ${ }^{3}$ Kursk Academy of State and Municipal Service, Kursk, Russian Federation; \\ 4*Plekhanov Russian University of Economics, Department of Accounting and Taxation Moscow, \\ Russian Federation \\ ${ }^{5}$ Kyrgyz-Russian Slavic University, Faculty of Humanities State Educational Institution \\ of Higher Vocational Education, Kyrgyz Republic;
}

*Corresponding Author Ravil Gabdullaevich Akhmadeev, email: ahm_rav@ mail.ru;

Received November 2021; Accepted December 2021; Published January 2022;

DOI: https://doi.org/10.31407/ijees12.126

\begin{abstract}
In order to solve the problems of the state budget deficit in the post-pandemic period in countries with developing economies, additional efforts are being made to maintain the stability of the national currency and the financial market. At the same time, in countries that provide tax revenues from oil revenues, measures are being taken that are aimed at introducing additional taxes and fees that directly affect the stimulation of investment activity in the field of hydrocarbon production. In this regard, the current tax innovations are aimed at the largest companies in the field of mining in order to generate additional revenues to the budget by revising the provided benefits and preferences for the subjects of the oil and gas sector. Taking into account the agreements adopted in 2020 at the level of the OPEC + countries on the limitation of oil production, undoubtedly, they will fully affect the revenues to the state budget of taxes levied on the extraction of minerals. At the same time, attention should be paid to a number of macroeconomic circumstances of the hydrocarbon sector of the economy of developing countries, namely, the degree of depreciation of fixed assets, since more than $50 \%$ of equipment in oil production and more than $80 \%$ of those employed in oil refining need to be updated. In this regard, when forming a concept for the development of hydrocarbon policy at the state level, it is important to provide for aspects aimed at increasing the effective return to the economy through the introduction of renewable alternative energy sources, taking into account the increased role of administration in terms of reducing $\mathrm{CO} 2$ emissions and shaping the role of the state's energy security.
\end{abstract}

Keywords: cultural approach, tax policy, emerging markets, natural resource rent, mineral resources, alternative energy. 